\title{
Transient Receptor Potential Channels in Intestinal Inflammation: What Is the Impact of Cigarette Smoking?
}

\author{
Liesbeth Allais $^{a} \quad$ Rebecca De Smet $^{a} \quad$ Stephanie Verschuere $^{b}$ Karel Talavera $^{c}$ \\ Claude A. Cuvelier ${ }^{a}$ Tania Maes ${ }^{d}$ \\ a Department of Medical and Forensic Pathology, Ghent University, Ghent, ${ }^{b}$ Department of Pathology, AZ Delta, \\ Roeselare, ' Laboratory of Ion Channel Research and TRP Research Platform Leuven, Department of Cellular and \\ Molecular Medicine, KU Leuven, Leuven, and ' Laboratory for Translational Research in Obstructive Pulmonary \\ Diseases, Department of Respiratory Medicine, Ghent University Hospital, Ghent, Belgium
}

\section{Key Words}

Transient receptor potential channels · Cigarette smoking · Intestinal inflammation

\begin{abstract}
Inflammatory bowel disease (IBD) is characterized by severe gastrointestinal inflammation and results from a complex interplay between genetic and environmental factors. IBD includes two prominent subtypes: Crohn's disease (CD) and ulcerative colitis (UC). One of the main risk factors for the development of $C D$ is cigarette smoking, while UC is rather a disease of ex-smokers. To date, many of the mechanisms underlying the immune imbalance in IBD and the involvement of cigarette smoke (CS) are incompletely understood. Transient receptor potential (TRP) proteins are non-selective cation channels that, upon activation, lead to plasma membrane depolarization and, in general, to $\mathrm{Ca}^{2+}$ influx. TRP channels of the ankyrin and vanilloid family, expressed by sensory neurons in the central and enteric nervous systems, have been extensively studied in the context of intestinal inflammation. Moreover, recent advances made on the role of non-neuronal expressed TRP channels shed light on the involvement of epithelial cells in inflammatory processes.
\end{abstract}

This review focuses on how CS may impact TRP channel function in intestinal inflammation. Firstly, we discuss the current knowledge on neuronal TRP channels, known to be linked to IBD, in health, immune homeostasis and intestinal inflammation. Subsequently, we address how TRP channels are activated by CS and its components in other organ systems and also hypothesize on the potential implications for CS-mediated TRP channel activation in gut inflammation.

๑) 2016 S. Karger AG, Basel

\section{Introduction}

Inflammatory bowel disease (IBD) is characterized by severe gastrointestinal inflammation and results from a complex interplay between genetic and environmental factors, of which cigarette smoking is the most prominent. IBD includes two main subtypes: Crohn's disease (CD) and ulcerative colitis (UC). The hallmarks of and differences between CD and UC are listed in table 1 .

C.A.C. and T.M. contributed equally to this paper.

\section{KARGER}

(c) 2016 S. Karger AG, Basel 
Table 1. Hallmarks of and differences between CD and UC

\begin{tabular}{|c|c|}
\hline Crohn's disease & Ulcerative colitis \\
\hline \multicolumn{2}{|l|}{ Clinical Features } \\
\hline Starts in the terminal ileum & Confined to the colon \\
\hline Can extend to any part of the gastrointestinal tract & Progress from distal to proximal \\
\hline Discontinuous (skip lesions, cobble stones) & Continuous \\
\hline \multicolumn{2}{|l|}{ Histology } \\
\hline Transmural inflammation & Superficial inflammation \\
\hline Acute and chronic inflammatory cell infiltrate & Acute and chronic inflammatory cell infiltrate \\
\hline Crypt architectural irregularity, ulcus (loss of crypts), cryptitis & $\begin{array}{l}\text { Cryptitis, crypt abscesses, branched and shortened crypts, crypt } \\
\text { regeneration + Paneth cell metaplasia }\end{array}$ \\
\hline Granulomas & Mucin granulomas (histiocytic aggregates, giant cells) \\
\hline- & Decreased mucus, decreased goblet cells \\
\hline \multicolumn{2}{|l|}{ Immunological response } \\
\hline Th1/17 response & Th2/17 response \\
\hline \multicolumn{2}{|l|}{ Oxidative stress } \\
\hline \multirow[t]{2}{*}{ Infiltration of neutrophils (source of ROS) } & Infiltration of neutrophils (source of ROS) \\
\hline & Increase of 4-HNE-modified proteins in the mucosa \\
\hline \multicolumn{2}{|l|}{ Important differential inflammatory mediators } \\
\hline $\begin{array}{l}\text { CD8+ T cell transcriptional signature as a potential } \\
\text { immunological marker }\end{array}$ & $\mathrm{LTB}_{4}$ as a major chemotactic factor for inflammatory cells \\
\hline Higher levels of CRP in serum & Higher levels of IL-13, IL-17 and CRP in serum \\
\hline \multirow[t]{2}{*}{ CRP levels in $\mathrm{CD}$ are even higher than in UC } & Disease activity correlates with amount of IL-13 and IL-17 \\
\hline & IL-17 as a progress marker for disease \\
\hline
\end{tabular}

Important shared inflammatory mediators in CD and UC

Increased IL-8 in the mucosa

Increased MCP-1 (mainly produced by macrophages, dendritic cells and monocytes)

Differential risk factors

Genetic defects: processing of intracellular bacteria, autophagy, Genetic defects: barrier function innate immunity

Antibiotic exposure, especially early in life

Cigarette smoking: detrimental

Diet: meats, fatty foods, desserts

Stress, depression
Antibiotic exposure

Cigarette smoking: protective

Diet: linoleic acid

\section{Shared risk factors in $C D$ and $U C$}

Geographic location, Western lifestyle

Hygiene hypothesis

Bacterial gastroenteritis

NSAID use

Vitamin D deficiency

Diet: high intake of mono- and disaccharides, total fats

For additional information on shared and differential cytokines in IBD, see the review by Neurath [4]. ROS = Reactive oxygen species.

In $\mathrm{CD}$, the whole intestinal wall is affected, resulting in transmural inflammation which can extend to any part of the intestine and is hallmarked by a complex set of phenotypes (ileal and/or colonic involvement) [1]. There is increasing interest in the use of immunological markers for prognosis. A potential immunological marker would be the CD8+ transcriptional signature [2]. In the serum of CD patients, higher levels of C-reactive protein (CRP) are detected [3]. Inflammation in $\mathrm{CD}$ is characterized by a T helper (Th) $1 / 17$ response [4]. 
In UC, inflammation is usually limited to the mucosal lining of the colon and rectum, and starts at the distal part of the gut, after which progression to more proximal regions occurs. The inflammatory mediator leukotriene $\mathrm{B} 4$ $\left(\mathrm{LTB}_{4}\right)$ is suggested to be a major chemotactic factor for inflammatory cells in UC [5]. In the serum of UC patients, higher levels of IL-13, IL-17 and CRP are found and disease activity is correlated with the amount of IL-13 and IL-17. IL-17 appears to be a major marker of disease progression in UC [6]. Inflammation in UC is characterized by a Th2/17 response [4].

In both $\mathrm{CD}$ and $\mathrm{UC}$, enhanced chemokine expression (e.g. IL-8) is correlated with increased disease activity in the colon of active patients, the amount of cells expressing monocyte chemoattractant protein (MCP)-1 is increased and IL-8 is increased in the mucosa [4-10].

It is being increasingly recognized that transient receptor potential (TRP) channels are implicated in bowel disorders and IBD $[11,12]$. These channels, named after the role of its founding member in Drosophila phototransduction $[13,14]$, are important sensors and transducers in the digestive system. They are cation-permeable channels and mediate the depolarization of cells upon activation by exogenous and local endogenous stimuli. Except for TRPM4 and TRPM5, all TRP channels are $\mathrm{Ca}^{2+}$ permeable, hence their activation impacts intracellular $\mathrm{Ca}^{2+}$ signaling [15]. Several TRP channels were first described as receptors sensitive to temperature changes and pungent or cooling spices. These channels function as molecular sensors for specific chemical entities, among which are painful toxins, playing a role in chemesthesis [16-18]. For example, capsaicin, a component of hot peppers, is a potent agonist of the TRP vanilloid 1 (TRPV1) channel $[19,20]$. Functional TRP channels consist of tetramers which open and close due to conformational changes in the protein structure [21-25]. To date, about 27 distinct TRP subunit genes are found to be encoded in the human genome. Five of the six identified subfamilies are implicated in chemo-, thermo- and/or mechanosensation, namely vanilloid TRP (TRPV), melastatin TRP (TRPM), ankyrin TRP (TRPA), polycystin TRP (TRPP) and canonical TRP (TRPC). The potential of TRP channels as a drug target in disease of the digestive system has been extensively reviewed before [26].

Cigarette smoke (CS) contains chemical irritants, e.g. nicotine and acrolein, which are known to activate TRP channels. In this way, CS may affect a diverse set of cellular pathways. Also, TRP channels are able to modulate the function of immune cells, e.g. CD4+ T cells [27, 28]. This review aims to provide an overview of what is cur-

TRP Channels and CS in Intestinal Inflammation rently known about the role of three TRP channels (TRPA1, TRPV1 and TRPV4) in the gut, their link with the immune system and their implications in inflammatory diseases of the intestine such as IBD. We hypothesize that a noxious substance like CS, which is able to interfere with the function of TRP channels in, for example, the lung, also impacts on TRP channel function in the gut, thereby providing a mechanistic link between cigarette smoking and gut disease.

\section{Function of TRP Channels in the Healthy Gut}

As cation entry pathways, TRP channels modulate many physiological processes. They play a role in the control of the membrane potential and excitability of neurons, epithelial cells, muscle cells and the interstitial cells of Cajal. TRP channels are also involved in the absorption of $\mathrm{Ca}^{2+}$ and $\mathrm{Mg}^{2+}$, and in the maintenance of blood flow, pacemaker activity, motor activity, secretion processes and mucosal homeostasis in the gut [26]. The main functions of TRP channels are molecular sensing of chemical and physical stimuli, downstream or secondary signal transduction via G-protein-coupled receptors (GPCRs) and ion transport. In primary afferent sensory neurons, TRP channels transduce signals, leading to the local release of neuropeptides such as calcitonin gene-related peptide (CGRP), substance $P$ and somatostatin, which modulate local tissue function. In addition, TRP channel activation affects the central nervous system, eventually causing autonomic reflex responses and sensations $[29,30]$.

The gut is extensively innervated and its function is controlled by both the extrinsic (autonomous) nervous system and its own local nervous system (called enteric or intrinsic nervous system). The enteric nervous system contains motor neurons that control digestive tract motility and primary afferent sensory nerves that detect chemical, mechanical or osmolarity changes in the gut. The gut lumen gets in contact with multiple chemicals, toxins and irritants that can be present in the ingested food, released by the intestinal tissue, produced by the microbial population or just present in the digestive fluids [26]. Due to their broadly tuned chemical sensitivities, sensory TRP channels play a role in the detection of these compounds (fig. 1). For example, although first being identified as a cold-activated channel, it was found that TRPA1 acts as a sensor for spices (e.g. mustard, horseradish and wasabi). In addition, TRPA1 is activated by endoand exogenous chemical irritants such as ozone, tear gas, nicotine and acrolein, among others [26, 31], and by al- 


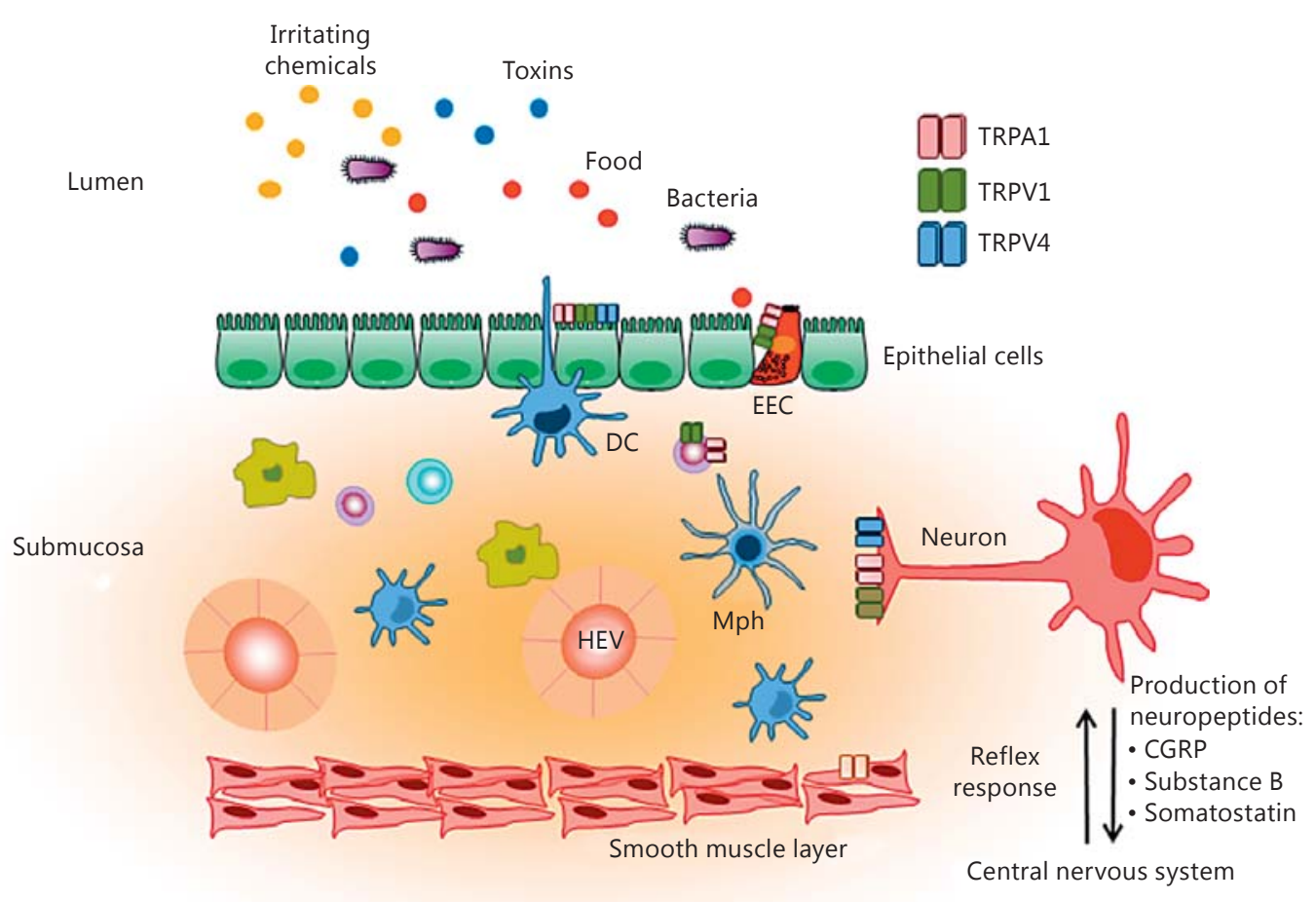

Fig. 1. Colocalization of TRP channels in the gut. The gut lumen contains a cocktail of irritating chemicals (e.g. nicotine, acrolein, ozone), toxins (e.g. from tropical plants and venoms), food constituents (e.g. pepper components), bacteria, etc. TRP channels are able to sense chemical and physical stimuli in the gut, among which are irritating chemicals, toxins and food constituents. The figure depicts the architecture of the intestinal wall, with the presence of intestinal epithelium including enteroendocrine cells, CD45+ immune cells and CD4+ T cells, muscle layer and neurons, and shows the location of TRPA1, TRPV1 and TRPV4 in the intestinal environment. $\mathrm{HEV}=$ high endothelial venule; $\mathrm{Mph}=$ macrophage; $\mathrm{EEC}=$ enteroendocrine cell. kalosis [32]. Another example is TRPV4, the activation of which is elicited by moderate heat, cell swelling and arachidonic acid metabolites [33]. A third example is TRPV1, which is a sensor for several spices, noxious heat, acidosis and endogenous stimuli (e.g. lipid mediators in the arachidonic acid metabolism) $[34,35]$.

\section{Localization of TRP Channels in the Gut}

The expression of TRP channels has been investigated using immunohistochemistry combined with retrograde tracing, with functional assays and by RT-qPCR and Western blotting. The channel TRPV1, belonging to the vanilloid subfamily, is found in extrinsic spinal and vagal primary afferent sensory neurons in the myenteric plexus (table 2), as shown in the mouse, rat and guinea-pig [11,
36-46]. The amount of TRPV1-expressing neurons depends on the gut region, higher in visceral than somatic afferent neurons [41, 47-49]. In rodents and human, TRPV1-expressing spinal and vagal neurons are present in the muscles and myenteric nerve plexuses, are associated with the arterioles and mucosa of the intestine and colocalize with CGRP, substance P, somatostatin and other neuropeptides and messenger molecules [11, 36$42,48,50-58]$. Some reports also suggest the existence of TRPV1-expressing neurons in the enteric nervous system, but this is still controversial [54]. An explanation might be the existence of distinct TRPV1 splice variants that show different immunoreactivity [59-61].

In addition to the nerves, non-neuronal cells can also express TRPV1 (fig. 1), e.g. the serous acinar and ductal cells of the human submandibular gland, the gastrin and parietal cells of the stomach, the epithelial cells of the 
Table 2. Expression of TRPA1, TRPV1 and TRPV4 on neuronal and non-neuronal cell types in the gut

\begin{tabular}{|c|c|c|c|c|c|}
\hline & Neuron & Epithelial cell & Enteroendocrine cell & Muscle cell & Immune cell $^{1}$ \\
\hline \multicolumn{6}{|c|}{ Channel } \\
\hline TRPA1 & + & + & + & & \\
\hline TRPV1 & + & + & + & & + \\
\hline TRPV4 & + & + & & + & + \\
\hline
\end{tabular}

${ }^{1}$ CD4+ T cell or CD45+ cell.

esophagus, stomach and ileum and the enteroendocrine cells, macrophages, CD4+ T cells and CD $45+$ cells in the gastrointestinal tract $[53,60,62-71]$.

TRPV4, another vanilloid TRP family member, has been reported to be expressed by primary spinal afferent sensory neurons and colocalizes with CGRP in the epithelial, submucosal and muscle cells in the intestine [72, 73]. In human tissue, TRPV4 has also been reported in intestinal epithelial, glial and infiltrated inflammatory cells [74]. In the human epithelial cell line Caco2, TRPV4 was found to be expressed at the basolateral side, but also weakly at the apical side [75].

Another example, from the ankyrin TRP family, is TRPA1. This channel has been shown to be expressed by extrinsic primary afferent and intrinsic enteric neurons and endocrine cells in the gut mucosa [26]. The activation of TRPA1, both in the esophagus and intestine, results in the excitation of primary afferent neurons in the vagal, splanchnic and pelvic nerves [76].

\section{Implication of TRP Channels in Immune Homeostasis of the Gastrointestinal Tract}

Upon activation of TRPA1- and TRPV1-expressing neurons, neurotransmitters are released, leading to changes in vascular, immune and smooth muscle functions in the intestine $[38,77-80]$. Importantly, TRPA1 and TRPV1 are implicated in the maintenance of immune homeostasis in the gastrointestinal tract through interaction with the microbiome.

TRP Channels and CS in Intestinal Inflammation
Although we focus on the lower gastrointestinal tract (ileum and colon) in this review, we include some insights on the upper gastrointestinal tract since these may also be of importance for other gut regions. For example, it has been shown that the function of TRPV1 in trigeminal neurons innervating the oral cavity can be modulated by the presence of endotoxin (lipopolysaccharide, LPS), an abundant outer wall glycolipid of Gram-negative bacteria [81]. Sensory neurons innervating the oral mucosa that express CGRP and TRPV1 also express immune receptors, such as the LPS receptor, Toll-like receptor 4 (TLR4) [81-84]. It has been reported that LPS as such cannot activate TRPV1 [81], but can increase the neuronal sensitivity towards TRPV1 agonists, yielding an increased release of CGRP (fig. 2) [81, 82]. CGRP not only increases neuronal sensitivity in the gut [84], but also has an anti-inflammatory role by binding to the CGRP receptor, which is expressed by immune cells, leading to a downregulation of TNF- $\alpha$ production by macrophages [85] and dendritic cells (DCs) [86].

For TRPA1, it has been shown that it can be activated by LPS in nociceptive neurons in a TLR4-independent manner, and that this channel mediates at least some acute LPS effects, including pain, inflammation, vasodilation and CGRP release (fig. 3) [87]. In addition, LPS-induced activation of TRPA1 is enhanced by 4-hydroxynonenal (4-HNE), an endogenous TRPA1 agonist produced by lipid peroxidation, indicating that this channel has increased sensitivity to LPS during inflammation [87]. To date, the involvement of TRPV4 in gut immune homeostasis remains unknown. Based on research on ciliated epithelial 


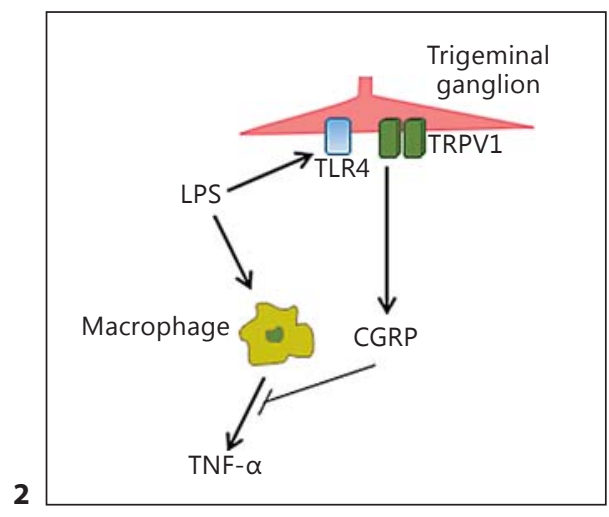

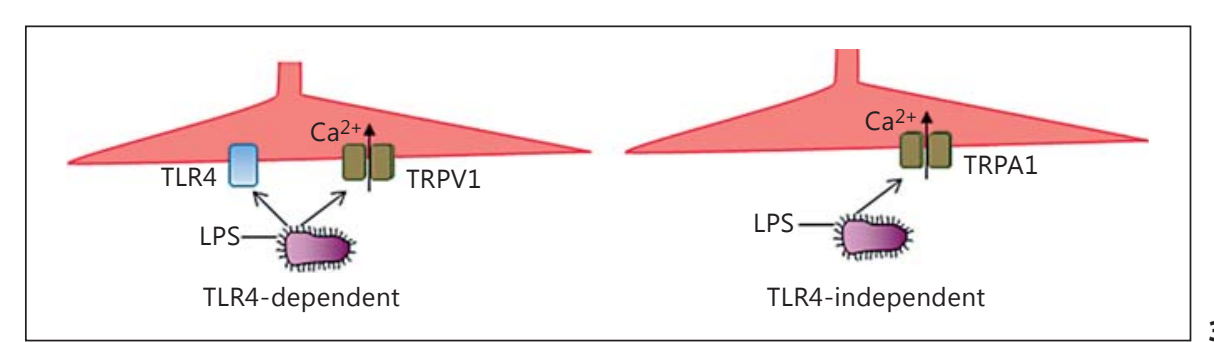

Fig. 2. Stimulation of the trigeminal ganglia inhibits LPS-induced production of TNF- $\alpha$ by macrophages.

Fig. 3. Involvement of TLR4 in LPS-mediated activation of TPRV1, but not TRPA1. cells (e.g. airways), this channel could be implicated in cell volume homeostasis and the regulation of ciliary activity [88]. However, gut and lung epithelia are very different, with lung epithelial cells bearing cilia, while gut epithelial cells have a characteristic brush border. Also, due to the functional differences between the ileum and colon, the role of TRP channels differs between these gut compartments. One may speculate that TRPV4 is involved in the evolution of immune homeostasis towards the onset of inflammation, as the channel's expression and function is modified by intestinal inflammation and its activation gives rise to proinflammatory signals [12].

\section{TRP Channels in the Inflamed Gut}

\section{TRPV1}

In addition to its role in gut homeostasis, TRPV1 is also involved in gut inflammation, pain and hyperalgesia [11]. Inflammation causes an upregulation and sensitization of TRPV1. In functional disorders such as irritable bowel syndrome (IBS) and quiescent UC and CD, a correlation has been shown between the amount of mucosal TRPV1-expressing neurons and pain severity [11]. Induction of TRPV1 protein in whole-gut tissue has been denoted in disorders of the lower gastrointestinal tract. Both CD and UC patients appear to have more TRPV1positive neurons in the rectosigmoid colon. The same observation has been made in IBS patients and patients with quiescent IBD showing IBS-like symptoms $[11,51]$. In addition, a study outside the gut showed that $\mathrm{LTB}_{4}$, a major inflammatory mediator in UC, induces itching of skin via TRPA1 and TRPV1 [89].

The TRPV1 channel exerts a nociceptive role, which is why its activation on primary afferent neurons causes the induction of pain. Many proalgesic factors affect TRPV1, and it seems that gut inflammation might be involved in the emergence of chemical and mechanical hyperalgesia [61, 90-92]. In inflammatory hypersensitivity, TRPV1 mainly functions as a secondary transducer, as its activity is boosted by mechanisms dependent on the receptors for inflammatory mediators and neurotrophins. IBS patients strongly suffering from diarrhea show hypersensitivity to food containing TRPV1 agonists (e.g. chili), resulting in painful and burning sensations [93]. In an experimental IBD mouse model like dextrane sodium sulfate (DSS) colitis, activated TRPV1 channels enhanced clinical symptoms, histological inflammation and neutrophil accumulation [94].

In cases of tissue irritation and injury, the activity of TRPV1 on vasculature, immune system and smooth muscles contributes to the development of neurogenic inflammation. CGRP, somatostatin and the tachykinins, substance $\mathrm{P}$ and neurokinin $\mathrm{A}$, are the messengers involved $[95,96]$. TRPV1 appears to have a dual role at the level of the gut mucosa. On the one hand, activation of TRPV1 protects the mucosa against injurious insults [77], and on the other hand, its activation causes stronger inflammation in models of colitis in wild-type mice compared to TRPV1 knock-out mice [94]. Also, the TRPV1 agonist capsaicin causes intestinal inflammation and the release of substance $\mathrm{P}$ in a similar way to Clostridium difficile toxin A. These effects can be abolished by the TRPV1 antagonist capsazepine [97].

\section{TRPV4}

TRPV4 is particularly known for its role in the pain pathway, as TRPV4 activation induces somatic and visceral pain $[26,73,98]$. TRPV4 is found to be increased in the inflamed gut tissue of human IBD patients (both UC 
and $\mathrm{CD}$ ) in comparison to healthy gut tissue, and its activation leads to inflammation $[74,75]$.

In the mouse, during DSS-induced colitis, TRPV4 mRNA and protein increases in colonic epithelium [75]. The increase of TRPV4 in the mouse colon during ongoing inflammation indicates a potential role for TRPV4 in intestinal inflammation [12]. TRPV4 function is regulated by inflammatory mediators. It has been shown that anti-inflammatory molecules such as plant cannabinoids decrease TRPV4 mRNA expression in the mouse jejunum (upper part of the ileum) [99], while proinflammatory molecules such as histamine, serotonin and proteases enhanced the neuronal response to TRPV4 activation in the mouse colon [98]. These proinflammatory mediators can induce the production of arachidonic acid metabolites, resulting in the activation of TRPV4 [98]. Also, selective blockade of TRPV4 in an IBD mouse model attenuated colitis and pain [74]. Intracolonic administration of TRPV4 agonists in wild-type mice causes inflammation-like tissue damage in the colon, with edema, hyperemia and prominent mucus production. This is accompanied with upregulated cytokines and chemokines such as IL-6, keratinocyte-derived chemokine (KC), MCP-1 and RANTES [75]. Furthermore, there is increased TRPV4 mRNA expression in colon biopsies of $\mathrm{CD}$ and UC patients, with the highest increase in UC patients [74].

Activation of TRPV4 by the synthetic agonist $4 a-$ phorbol-12,13-didecanoate (4aPDD) elicits inflammation via a neurogenic mechanism, which includes the release of neuropeptides (substance P and CGRP) by sensory neurons. In the gut, intraluminal administration of TRPV4 agonists results in activation of nociceptors, visceral hyperalgesia and allodynia [73, 98].

Many studies have investigated the role of neuronal TRPV4 in intestinal inflammation. Recent research is also focusing on epithelial TRPV4, mainly via in vitro studies. For example, it has been shown that TRPV4 activation triggers IL-8 production in esophageal epithelial cells [100]. In the intestinal epithelial cell lines, Caco 2 and T84, TRPV4 activation by 4aPDD leads to a dose-dependent increase in intracellular $\mathrm{Ca}^{2+}$ concentration and chemokine release [75]. These findings in epithelial cell lines suggest that TRPV4 may play a role in intestinal inflammation via a non-neurogenic mechanism, leading to the production of chemokines such as IL-8.

\section{TRPA1}

TRPA1 is upregulated in colitis in mice and in colon biopsies of human UC and CD patients [69]. The activa- tion of TRPA1 on visceral sensory neurons causes the release of neuropeptides, which results in vasodilatation, local inflammation and sustained mechanical hyperalgesia in the gut [101-103]. In the literature, both proand anti-inflammatory effects have been attributed to TRPA1. For example, it has been shown that TRPA1 agonists are able to elicit colitis, associated with an increased TRPA1 protein expression in sensory neurons [104]. DSS colitis was found to be less severe in mice deficient for TRPA1, although DSS is not a direct activator of sensory neurons; it seems that the colitis was maintained due to a sustained activation of TRPA1 by endogenous inflammatory stimuli (e.g. prostaglandins, cytokines and oxidative stress mediators like 4-HNE and acrolein) [105]. In contrast, another study showed that the TRPA1 agonist AITC causes a protective effect in experimentally induced gastritis in rats, probably via endogenous prostaglandins [106]. Moreover, the IL-6 signal transducer gp130 is indispensable for expression of the TRPA1 ion channels in the dorsal root ganglia, suggesting that TRPA 1 is prone to proinflammatory signals like IL-6 [107]. TRPA1 mRNA expression is increased in whole colon tissue in murine colitis and in human biopsies of active CD and UC patients. Furthermore, a protective role has been attributed to TRPA1 in the gut, as its ablation ameliorates the disease activity index and histological score in DSS colitis, and TRPA1 mediates the decrease in proinflammatory neuropeptides, cytokines and chemokines [69].

\section{Other TRP Channels}

Besides TRPV1, TRPV4 and TRPA1, knowledge about other TRP channels in gut disease is limited. TRPV6, mainly expressed by intestinal epithelial cells and the colon cell line, $\mathrm{Caco} 2$, is highly selective for $\mathrm{Ca}^{2+}$ transport and is therefore important for $\mathrm{Ca}^{2+}$ absorption in the gut [108-110]. This channel is regulated by dietary factors and calciotropic hormones [108, 111-114]. Disturbed $\mathrm{Ca}^{2+}$ homeostasis is associated with a CD-like pathology and may lead to osteoporosis [115].

\section{Interaction between TRP Channels and CS in the Lung}

In Belgium, $27 \%$ of the population smokes, with the highest percentages being amongst men, the unemployed and workers [116]. CS is amongst the three leading risk factors for global disease burden [117]. In comparison to never-smokers, current smokers have a 2-3 times higher 
Table 3. TRP activation in non-neuronal cell types

\begin{tabular}{|c|c|c|c|c|}
\hline Cell type & TRP channel & Activating component & Effect & Reference \\
\hline Human lung fibroblasts & TRPA1 & $\begin{array}{l}\text { whole CS } \\
\text { acrolein }\end{array}$ & induction of IL-8/KC & {$[110]$} \\
\hline Human esophageal cells & TRPV1 & 4-HNE & induction of IL-8 & {$[117]$} \\
\hline Human intestinal epithelial cells & TRPV4 & $4 a \mathrm{PDD}$ & induction of IL-8 & {$[61]$} \\
\hline
\end{tabular}

mortality rate. The major causes of death include lung cancer, chronic obstructive pulmonary disease (COPD), ischemic heart disease and total stroke [118]. In the lung, CS causes an increase in inflammatory cells, including DCs, CD8+ and CD4+ T cells, in the airways and pulmonary tissue, leading to the development of lymphoid neogenesis and COPD. Many cytokines, chemokines and their receptors are involved in this immunological response, such as MCP-1, IL-8 and CCR6 [119].

TRP channels have been linked to pathological conditions of the lung. For example, they are often related to cough and wheezing in asthma patients, e.g. TRPV1 is increased in airway nerves and airway smooth muscle cells of individuals with cough [120]. Single nucleotide polymorphisms (SNPs) in the TRPV1 gene are also linked to cough [120]. TRPA1 has been shown to play a role in neuro-immune interactions in the airways, giving rise to asthmatic airway inflammation after allergen challenge [121]. Furthermore, gene polymorphisms of TRPV4 have been associated with COPD [88].

The interaction between the chemical irritants contained in CS and TRP channels has been studied in the lung-innervating neurons. For instance, TRPA1 is known to be sensitive to various irritants and chemicals, among which are air pollutants and prominent CS components [122]. In addition, nicotine is able to activate TRPA1, although at concentrations higher than those found in CS, but relevant for smoking cessation therapies [123].

TRP channels are expressed in a subpopulation of primary sensory neurons in the airways. Upon activation, these neuronal TRPs may give rise to neurogenic inflammation, which implies the release of proinflammatory neuropeptides, such as substance P and CGRP [46, 87]. However, TRP channels are also expressed by non-neuronal cells (table 3 ), among which are immune and epithelial cells $[70,124]$, thus contributing to acute inflammatory responses in the lung in response to CS or one of its components. Indeed, the TRPA 1 agonists acrolein and CS were able to induce release of IL-8/KC by epithelial cells in primary cell culture [124]. Furthermore, TRPV1 and TRPV4 mRNA levels are increased in lung tissue from COPD patients and both channels mediate ATP release from bronchial epithelial cells [125].

\section{Impact of CS on TRP Channels in the Gut?}

Few studies have probed the effect of CS on TRP channels in the gut. There are important similarities in the molecular effects of CS in the lungs and the gut (fig. 4), which makes it interesting to investigate whether it similarly affects the TRP channels in the gut and lungs. Nevertheless, many differences exist between lung and gut epithelia, not in the least in their function. In both the lungs and gut, the epithelium acts as a barrier, but lung epithelial cells play a role in, e.g. mucociliary transport, while gut epithelial cells, with their characteristic brush border, are rather involved in digestion. TRP channels are expressed and play a role in both the lungs and gut, CS affects TRP channels in the lung and the expression of TRPs is increased in the gut of IBD patients $[69,124]$. Therefore, it is likely that CS also affects TRP channels in the gut.

Cigarette smoking is a major modulating factor in the development of IBD. First, it worsens CD, necessitating increased need for steroids and immunosuppressive drugs, more frequent relapses and surgery [126]. Moreover, current smokers have a two times higher risk and ex-smokers have a 1.8 times higher risk of developing CD in comparison to never-smokers. In contrast, UC occurs in ex-smokers, as shown by several meta-analyses [127135], and the risk of developing UC is three times higher in the first five years after smoking cessation [127].

Several mechanisms are suggested to be responsible for the negative effect of cigarette smoking in CD patients. It is known that CS causes an increased expression of IL-8, CCR6, CCL20 and mucins, induction of autophagy and apoptosis, increased recruitment of immune cells and a decrease in IFN- $\gamma$ (fig. 4) in the ileum. Furthermore, the oxidizing chemicals contained in CS can have prothrombotic effects, and thereby trigger microvasculature 
Fig. 4. Effects of cigarette smoking on the gut and lungs.

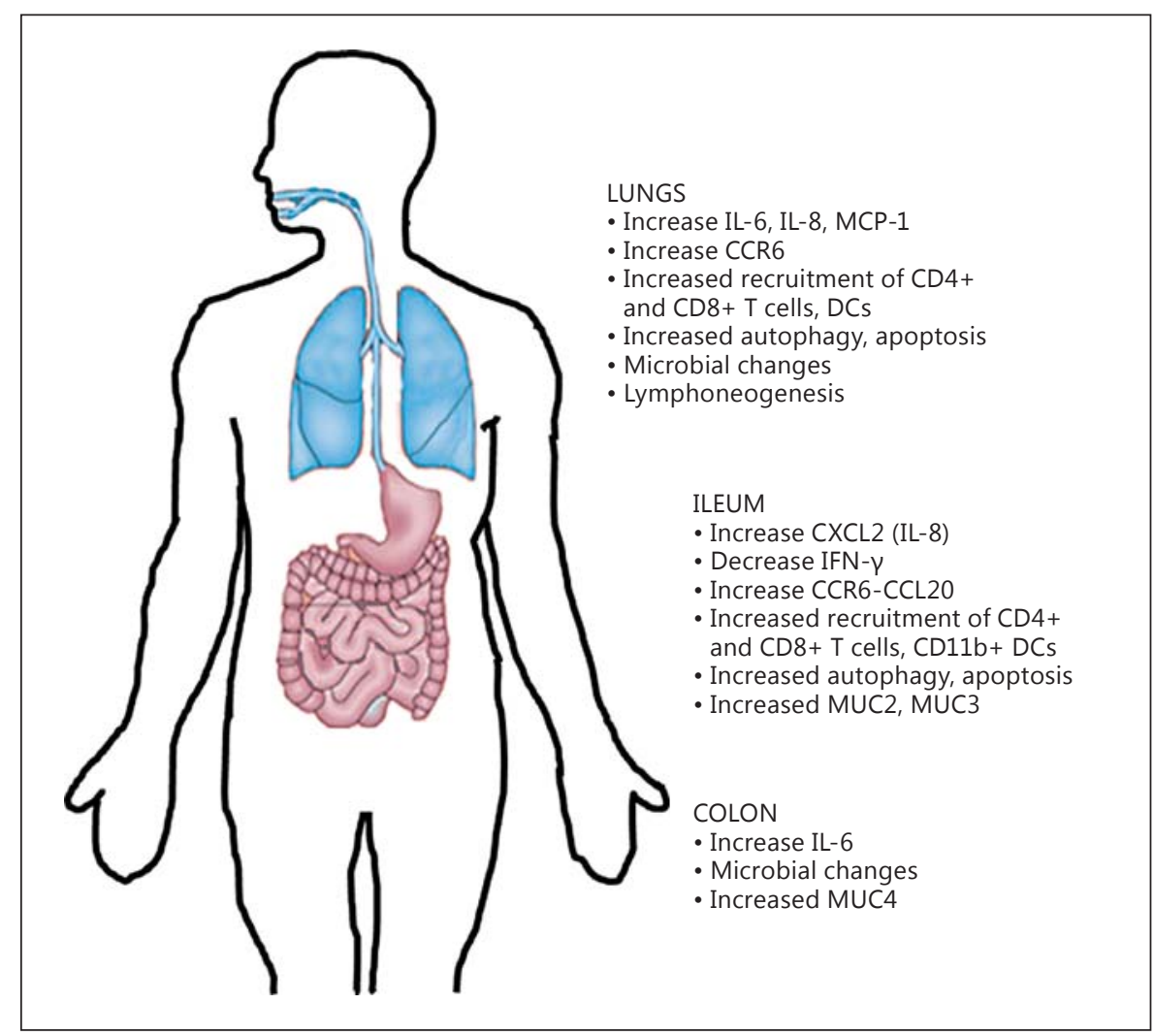

abnormalities and ischemia in the gut. Also, the impaired bacteria-host response, which is a hallmark of $\mathrm{CD}$, can be worsened by smoking, as it exerts an immunosuppressive effect on macrophages [136, 137]. Different mechanisms might be at the base of the differential smoke-induced effects in CD and UC patients. Indeed, the main sites of inflammation differ between these two diseases: CD mainly occurs in the terminal ileum while UC is usually initiated in the distal colon. The fundamental difference between the ileum and the colon can possibly explain why CS may exert its effect on CD and UC via very different mechanisms. The situation is more complex in the colon than in the ileum due to the numerously present microbiota. The effect of CS on the colon is ambiguous, even though epidemiological evidence clearly shows a protective effect of CS on UC. The most important effect of CS on the colon is a prominent shift in microbiome composition and activity [138]. To date, the exact mechanisms which underlie the differential effects of CS on CD and UC remain a matter of debate. For example, it has been suggested that differential DC responses to CS between CD and UC may play a role [139]. Another study suggests that CS induces barrier dysfunction in the ileum, but not in the colon [140]. IL-8 is also known to be increased in the mucosa of UC and CD patients [7-10]. A study reported that CS affects IL-8 levels in the mucosa of UC and CD patients [141]. Of course, the gut is a very complex organ system with complex functions (e.g. the interaction immune system-microbiome). The effect of CS on the gut is probably a combination of several mechanisms.

In a mouse model, we have demonstrated that, similarly to the lung, CS affects the gut immune system by enhancing the recruitment of CD11b+ DCs, CD4+ and CD8+ T cells to the mouse ileal Peyer's patches, which are the main lymphoid organs in the gut [142]. Furthermore, CS alters the production of immune factors in the mouse ileum (increased CXCL2, an IL-8 homolog) and in the proximal colon (increased IL-6) [138]. Therefore, it is likely that CS exerts its effect on gut inflammation via mechanisms similar to the lung, with the levels of similar cytokines (IL-6 and IL-8), chemokines (MCP-1) and receptors (CCR6) being increased by CS $[119,143]$.

We speculate that CS and its components activate TRP channels in the gut, which can lead to increased cytokine production and, in this way, predispose the gut environment for the development of inflammation. How CS has 
a differential effect on TRP channels in UC and CD is unknown; however, different hypotheses can be put forward. First, differences in innervation between the ileum and the colon could contribute to a different role for TRP channels in CD and UC. Whereas both the ileum and colon are supplied with autonomic and sensory fibers from the celiac and superior mesenteric plexuses, the colon is additionally innervated by the pelvic nerves. Differences in the distribution of TRP-expressing sensory neurons between the ileum and colon as well as the degree of TRP expression could maybe contribute to the different responses in CD and UC towards CS. For example, a study has shown that TRPV1 expression (in the submucosa, smooth muscle layer and myenteric plexus) is elevated in the distal part of the colon in comparison to the proximal part [144]. Secondly, differential TRP expression and activation on epithelial cells and/or inflammatory cells in different parts of the gastrointestinal tract could be implicated in the two pathologies. According to a study by Kun et al. [69], mainly TRPA1 and TRPV1-immunopositive macrophages are detected in UC, while TRPA1- and TRPV1-immunopositive infiltrating plasma cells are more prominent in CD. Finally, differences in microbial composition between distinct gut regions and the potential interaction of bacterial components with TRP channels could play a role. CS differentially affects CD and UC, and prominent effects of CS on the microbial composition in the colon have been reported [138, 145]. This is particularly interesting as LPS (a component of the microbial cell wall)-TLR4 interactions are able to sensitize e.g. TRPV1. Gut epithelial cells express both TRPV1 and TLRs. However, probiotics such as Lactobacillus are able to reduce TRPV1 activation. It may be that CS indirectly affects the TRP channels in the colon via the induction of changes in the microbiome, but these effects will strongly depend on which species and niches are changed and whether microbial metabolism and the resulting metabolite pool are affected. Taken together, the differential effects of CS in CD and UC could originate from the CSinduced changes in the microbiome in the colon, which can modulate TRP channel activity.

It is particularly interesting that activation of the TRP channels can boost IL-8 expression (e.g. in the lungs). Furthermore, as ion channels, TRP channels can also affect cellular processes (e.g. via $\mathrm{Ca}^{2+}$ entry) and their activation can have far reaching consequences for the cell. It might be interesting to examine whether $\mathrm{CS}$ affects $\mathrm{Ca}^{2+}$ inflow and $\mathrm{Ca}^{2+}$-dependent cellular processes. An example is autophagy, which is known to be induced by CS in the epithelium of both the lungs and ileum [11, 12, 146-
148]. The activation of immune cells can also be modulated through $\mathrm{Ca}^{2+}$ inflow. In CD4+ T cells, TRPV1 is associated with $\mathrm{T}$ cell receptor (TCR) co-receptor CD4 and contributes to TCR-induced $\mathrm{Ca}^{2+}$ inflow [27]. Altogether, these data suggest that TRP channels may contribute to inflammation in the ileum, and they possibly play a role in the detrimental effect of CS on CD.

Surprisingly, in IBD genome-wide association studies (GWAS), no SNPs in TRP genes have been found to be associated with IBD [149]. Nevertheless, TRP function is often associated with factors that do show significant polymorphisms in IBD GWAS, e.g. TLR4, ATG16L1 [81, 150]. However, in lung disease, SNPs in TRP channels are found. Trpv4 gene polymorphisms are associated with COPD [151] and Trpv1 genetic variants are linked with a lower risk of active childhood asthma [152]. It might be that the IBD GWAS did not detect any Trp polymorphisms, because the studies did not focus on specific risk factors such as CS. A specific genetic study taking CS into account as a cofactor would be needed to verify this hypothetical statement.

In addition, it is known that CS affects extraintestinal manifestations of IBD, specifically rheumatoid arthritis. Interestingly, TRP channels also play a role in rheumatoid arthritis, with TRPA1 and TRPV1 involved in the anti-inflammatory effects of $\mathrm{N}$-acylethanolamines in rheumatoid arthritis synovial cells [153].

Furthermore, the link with functional disorders such as IBS might be of interest. A study has shown that TRPV1 is increased in rectosigmoid biopsies of patients with IBS and quiescent IBD. TRPV1 expression clearly correlated with increased pain perception [11]. This may point to a link between IBS and colonic IBD.

Neuronal TRPs have been thoroughly studied in the gut [26], but not in relation to CS. The number of studies regarding the effects of CS on epithelial TRP channel expression and function in the gut is scarce. Several studies have probed the effects of CS components on TRPV1 and TRPV4 in in vitro cell culture models (table 3 ). In human esopagheal epithelial cells, the activation of TRPV1 also leads to the induction of IL-8, and this induction is further enhanced by 4-HNE, which is released upon CS- and inflammation-induced oxidative stress. One of the stressinducing capacities of 4-HNE is the modification of proteins. Moreover, the TRPV1 protein itself is modified by 4-HNE [154]. TRPV1's cytokine-inducing capacity is modulated by oxidative stress, due to reactive oxygen species which are present in both the particulate and gaseous phase of CS [69].
Allais/De Smet/Verschuere/Talavera/ Cuvelier/Maes 
In conclusion, there are indications that CS may affect TRPs in the gut in a similar way to how it affects TRPs in the lung. This concerns an immunomodulatory role via the induction of cytokines like IL-8, e.g. in the case of epithelial TRPs, but this may even extend to cellular processes like autophagy. This CS-TRP interaction may provide the mechanistic link between CS and IBD. Of course, further studies, taking into account the substantial differences between the distinct gut compartments (ileum and colon), are needed to unravel the role of TRP channels in the pathogenesis of gut disease.

\section{Acknowledgements}

Liesbeth Allais is supported by a doctoral grant from the Special Research Fund of Ghent University (01D41012). This work was funded by the Belgian Federal Government (IAP P7/30, IAP P7/13), FWO Flanders (G.A022, G.0702.12, G.0896.12 and G.0C77.15), a Ghent University Concerted Research Action (BOF14-GOA-027) and the Research Council of the KU Leuven (GOA/14/011 and PF-TRPLe).

\section{Disclosure Statement}

No author has an ethical or financial conflict of interest.

\section{References}

1 Podolsky DK: Inflammatory bowel disease. N $>11$ Akbar A, Yiangou Y, Facer P, Brydon WG, Engl J Med 2002;347:417-429.

2 Vermeire S, Van Assche G, Rutgeerts P: Classification of inflammatory bowel disease: The old and the new. Curr Opin Gastroenterol 2012;28:321-326.

3 Vermeire S, Van Assche G, Rutgeerts P: Laboratory markers in IBD: useful, magic, or unnecessary toys? Gut 2006;55:426-431.

4 Neurath MF: Cytokines in inflammatory bowel disease. Nat Rev Immunol 2014;14: 329-342.

5 Lobos EA, Sharon P, Stenson WF: Chemotactic activity in inflammatory bowel disease. Role of leukotriene B4. Digest Dis Sci 1987;32: 1380-1388.

6 Boldeanu MV, Silosi I, Ghilusi M, Cojocaru M, Biciusca V, Avramescu CS, Cojocaru IM, Ciurea T, Albu DF, Silosi CA: Investigation of inflammatory activity in ulcerative colitis. Rom J Morphol Embryol 2014;55:1345-1351.

7 Korolkova OY, Myers JN, Pellom ST, Wang L, M'Koma AE: Characterization of serum cytokine profile in predominantly colonic inflammatory bowel disease to delineate ulcerative and Crohn's colitides. Clin Med Insights Gastroenterol 2015;8:29-44.

8 Thelen M, Peveri P, Kernen P, von Tscharner V, Walz A, Baggiolini M: Mechanism of neutrophil activation by NAF, a novel monocytederived peptide agonist. FASEB J 1988;2: 2702-2706.

9 Thomsen MK, Larsen CG, Thomsen HK, Kirstein D, Skak-Nielsen T, Ahnfelt-Ronne I, Thestrup-Pedersen K: Recombinant human interleukin-8 is a potent activator of canine neutrophil aggregation, migration, and leukotriene B4 biosynthesis. J Invest Dermatol 1991;96:260-266.

10 Daig R, Andus T, Aschenbrenner E, Falk W, Scholmerich J, Gross V: Increased interleukin 8 expression in the colon mucosa of patients with inflammatory bowel disease. Gut 1996; 38:216-222. Walters JR, Anand P, Ghosh S: Expression of the TRPV1 receptor differs in quiescent inflammatory bowel disease with or without abdominal pain. Gut 2010;59:767-774.

12 Vergnolle N: Trpv4: New therapeutic target for inflammatory bowel diseases. Biochem Pharmacol 2014;89:157-161.

13 Montell C, Rubin GM: Molecular characterization of the Drosophila TRP locus: A putative integral membrane protein required for phototransduction. Neuron 1989;2:13131323.

14 Hardie RC, Minke B: The TRP gene is essential for a light-activated Ca2+ channel in Drosophila photoreceptors. Neuron 1992;8:643651.

15 Bourinet E, Altier C, Hildebrand ME, Trang T, Salter MW, Zamponi GW: Calcium-permeable ion channels in pain signaling. Physiol Rev 2014;94:987-987.

16 Roper SD: TRPs in taste and chemesthesis. Handb Exp Pharmacol 2014;223:827-871.

17 Alpizar YA, Voets T, Talavera K: Molecular mechanisms underlying the role of TRP channels in chemesthesis; in McDonald ST, Bolliet DA, Hayes JE (eds): Chemesthesis: Chemical Touch in Food and Eating. Chichester, Wiley Blackwell, 2016.

18 Boonen B, Startek JB, Talavera K: Chemical activation of sensory TRP channels; in: Topics in Medicinal Chemistry. Springer, 2016, pp $1-41$.

19 Caterina MJ, Schumacher MA, Tominaga M, Rosen TA, Levine JD, Julius D: The capsaicin receptor: a heat-activated ion channel in the pain pathway. Nature 1997;389:816-824.

20 Caterina MJ, Leffler A, Malmberg AB, Martin WJ, Trafton J, Petersen-Zeitz KR, Koltzenburg M, Basbaum AI, Julius D: Impaired nociception and pain sensation in mice lacking the capsaicin receptor. Science 2000;288:306313.
21 Hoenderop JG, Voets T, Hoefs S, Weidema F, Prenen J, Nilius B, Bindels RJ: Homo- and heterotetrameric architecture of the epithelial Ca2+ channels TRPV5 and TRPV6. EMBO J 2003;22:776-785.

22 Moiseenkova-Bell VY, Stanciu LA, Serysheva, II, Tobe BJ, Wensel TG: Structure of TRPV1 channel revealed by electron cryomicroscopy. Proc Natl Acad Sci USA 2008;105:7451-7455.

23 Janssens A, Voets T: Ligand stoichiometry of the cold- and menthol-activated channel TRPM8. J Physiol 2011;589:4827-4835.

24 Liao M, Cao E, Julius D, Cheng Y: Structure of the TRPV1 ion channel determined by electron cryo-microscopy. Nature 2013;504: 107-112.

-25 Paulsen CE, Armache JP, Gao Y, Cheng Y, Julius D: Structure of the TRPA1 ion channel suggests regulatory mechanisms. Nature 2015;525:552.

26 Holzer P: Transient receptor potential (TRP) channels as drug targets for diseases of the digestive system. Pharmacol Ther 2011;131: 142-170.

27 Bertin S, de Jong PR, Jefferies WA, Raz E: Novel immune function for the TRPV1 channel in T lymphocytes. Channels 2014;8:479480.

28 Bertin S, Raz E: Transient receptor potential (TRP) channels in T cells. Semin Immunopathol 2016;38:309-319.

29 Holzer P: Local effector functions of capsaicin-sensitive sensory nerve endings: involvement of tachykinins, calcitonin gene-related peptide and other neuropeptides. Neuroscience 1988;24:739-768.

30 Maggi CA, Meli A: The sensory-efferent function of capsaicin-sensitive sensory neurons. Gen Pharmacol 1988;19:1-43.

31 Story GM, Peier AM, Reeve AJ, Eid SR, Mosbacher J, Hricik TR, Earley TJ, Hergarden AC, Andersson DA, Hwang SW, McIntyre P, Jegla T, Bevan S, Patapoutian A: ANKTM1, a TRPlike channel expressed in nociceptive neurons, is activated by cold temperatures. Cell 2003;112:819-829.
TRP Channels and CS in Intestinal Inflammation 
-32 Fujita F, Uchida K, Moriyama T, Shima A, Shibasaki K, Inada H, Sokabe T, Tominaga M: Intracellular alkalization causes pain sensation through activation of TRPA1 in mice. J Clin Invest 2008;118:4049-4057.

- 33 Vincent F, Duncton MA: TRPV4 agonists and antagonists. Curr Top Med Chem 2011;11: 2216-2226.

-34 Moran MM, McAlexander MA, Biro T, Szallasi A: Transient receptor potential channels as therapeutic targets. Nat Rev Drug Discov 2011;10:601-620.

-35 Banner KH, Igney F, Poll C: Trp channels: Emerging targets for respiratory disease. Pharmacol Therapeut 2011;130:371-384.

-36 Patterson LM, Zheng H, Ward SM, Berthoud HR: Vanilloid receptor (VR1) expression in vagal afferent neurons innervating the gastrointestinal tract. Cell Tissue Res 2003;311:277287.

- 37 Ward SM, Bayguinov J, Won KJ, Grundy D, Berthoud HR: Distribution of the vanilloid receptor (VR1) in the gastrointestinal tract. J Comp Neurol 2003;465:121-135.

-38 Holzer P: Vanilloid receptor TRPV1: hot on the tongue and inflaming the colon. Neurogastroenterol Motil 2004;16:697-699.

- 39 Horie S, Yamamoto H, Michael GJ, Uchida M, Belai A, Watanabe K, Priestley JV, Murayama T: Protective role of vanilloid receptor type 1 in HCL-induced gastric mucosal lesions in rats. Scand J Gastroenterol 2004;39: 303-312.

40 Kadowaki M, Kuramoto H, Takaki M: Combined determination with functional and morphological studies of origin of nerve fibers expressing transient receptor potential vanilloid 1 in the myenteric plexus of the rat jejunum. Auton Neurosci 2004;116:11-18.

-41 Robinson DR, McNaughton PA, Evans ML, Hicks GA: Characterization of the primary spinal afferent innervation of the mouse colon using retrograde labelling. Neurogastroenterol Motil 2004;16:113-124.

-42 Schicho R, Florian W, Liebmann I, Holzer P, Lippe IT: Increased expression of TRPV1 receptor in dorsal root ganglia by acid insult of the rat gastric mucosa. Eur J Neurosci 2004; 19:1811-1818.

43 Banerjee B, Medda BK, Lazarova Z, Bansal N, Shaker R, Sengupta JN: Effect of reflux-induced inflammation on transient receptor potential vanilloid one (TRPV1) expression in primary sensory neurons innervating the oesophagus of rats. Neurogastroenterol Motil 2007;19:681-691.

-44 Ryu JJ, Yoo S, Kim KY, Park JS, Bang S, Lee SH, Yang TJ, Cho H, Hwang SW: Laser modulation of heat and capsaicin receptor TRPV1 leads to thermal antinociception. J Dent Res 2010;89:1455-1460.

-45 Zhao H, Simasko SM: Role of transient receptor potential channels in cholecystokinin-induced activation of cultured vagal afferent neurons. Endocrinology 2010;151:52375246.
46 Engel MA, Khalil M, Mueller-Tribbensee SM, Becker C, Neuhuber WL, Neurath MF, Reeh PW: The proximodistal aggravation of colitis depends on substance $\mathrm{P}$ released from TRPV1-expressing sensory neurons. J Gastroenterol 2012;47:256-265.

47 Brierley SM, Carter R, Jones W 3rd, Xu L, Robinson DR, Hicks GA, Gebhart GF, Blackshaw LA: Differential chemosensory function and receptor expression of splanchnic and pelvic colonic afferents in mice. J Physiol 2005;567:267-281.

48 Hwang SJ, Oh JM, Valtschanoff JG: Expression of the vanilloid receptor TRPV1 in rat dorsal root ganglion neurons supports different roles of the receptor in visceral and cutaneous afferents. Brain Res 2005;1047:261266.

49 Christianson JA, McIlwrath SL, Koerber HR, Davis BM: Transient receptor potential vanilloid 1-immunopositive neurons in the mouse are more prevalent within colon afferents compared to skin and muscle afferents. Neuroscience 2006;140:247-257.

50 Facer P, Knowles CH, Tam PK, Ford AP, Dyer N, Baecker PA, Anand P: Novel capsaicin (VR1) and purinergic (P2X3) receptors in Hirschsprung's intestine. J Pediatr Surg 2001; 36:1679-1684.

51 Yiangou Y, Facer P, Dyer NH, Chan CL, Knowles C, Williams NS, Anand P: Vanilloid receptor 1 immunoreactivity in inflamed human bowel. Lancet 2001;357:1338-1339.

52 Matthews PJ, Aziz Q, Facer P, Davis JB, Thompson DG, Anand P: Increased capsaicin receptor trpv1 nerve fibres in the inflamed human oesophagus. Eur J Gastroenterol Hepatol 2004;16:897-902.

53 Zhang L, Jones S, Brody K, Costa M, Brookes SJ: Thermosensitive transient receptor potential channels in vagal afferent neurons of the mouse. Am J Physiol Gastrointest Liver Physiol 2004;286:G983-G991.

-54 Green T, Dockray GJ: Characterization of the peptidergic afferent innervation of the stomach in the rat, mouse and guinea-pig. Neuroscience 1988;25:181-193.

55 Holzer P: Capsaicin: Cellular targets, mechanisms of action, and selectivity for thin sensory neurons. Pharmacol Rev 1991;43:143201.

56 Sternini C, Anderson K: Calcitonin gene-related peptide-containing neurons supplying the rat digestive system: differential distribution and expression pattern. Somatosens Mot Res 1992;9:45-59.

57 Szallasi A, Blumberg PM: Vanilloid (capsaicin) receptors and mechanisms. Pharmacol Rev 1999;51:159-212.

58 Price TJ, Flores CM: Critical evaluation of the colocalization between calcitonin gene-related peptide, substance $\mathrm{P}$, transient receptor potential vanilloid subfamily type 1 immunoreactivities, and isolectin b4 binding in primary afferent neurons of the rat and mouse. J Pain 2007;8:263-272.
59 Wang C, Hu HZ, Colton CK, Wood JD, Zhu MX: An alternative splicing product of the murine TRPV1 gene dominant negatively modulates the activity of TRPV1 channels. J Biol Chem 2004;279:37423-37430.

-60 Faussone-Pellegrini MS, Taddei A, Bizzoco E, Lazzeri M, Vannucchi MG, Bechi P: Distribution of the vanilloid (capsaicin) receptor type 1 in the human stomach. Histochem Cell Biol 2005;124:61-68.

61 Szallasi A, Cortright DN, Blum CA, Eid SR: The vanilloid receptor TRPV1:10 years from channel cloning to antagonist proof-of-concept. Nat Rev Drug Discov 2007;6:357-372.

62 Ding QW, Zhang Y, Wang Y, Wang YN, Zhang L, Ding C, Wu LL, Yu GY: Functional vanilloid receptor-1 in human submandibular glands. J Dent Res 2010;89:711-716.

-63 Nozawa Y, Nishihara K, Yamamoto A, Nakano M, Ajioka H, Matsuura N: Distribution and characterization of vanilloid receptors in the rat stomach. Neurosci Lett 2001;309:3336.

64 Kato S, Aihara E, Nakamura A, Xin H, Matsui $\mathrm{H}$, Kohama K, Takeuchi K: Expression of vanilloid receptors in rat gastric epithelial cells: role in cellular protection. Biochem Pharmacol 2003;66:1115-1121.

65 Kechagias S, Botella S, Petersson F, Borch K, Ericson AC: Expression of vanilloid receptor-1 in epithelial cells of human antral gastric mucosa. Scand J Gastroenterol 2005;40:775782 .

66 Cheng L, de la Monte S, Ma J, Hong J, Tong M, Cao W, Behar J, Biancani P, Harnett KM: HCL-activated neural and epithelial vanilloid receptors (TRPV1) in cat esophageal mucosa. Am J Physiol Gastrointest Liver Physiol 2009; 297:G135-G143.

67 Ericson A, Nur EM, Petersson F, Kechagias S: The effects of capsaicin on gastrin secretion in isolated human antral glands: before and after ingestion of red chilli. Dig Dis Sci 2009;54: 491-498.

68 Ma J, Harnett KM, Behar J, Biancani P, Cao W: Signaling in TRPV1-induced platelet activating factor (PAF) in human esophageal epithelial cells. Am J Physiol Gastrointest Liver Physiol 2010;298:G233-G240.

69 Kun J, Szitter I, Kemeny A, Perkecz A, Kereskai L, Pohoczky K, Vincze A, Godi S, Szabo I, Szolcsanyi J, Pinter E, Helyes Z: Upregulation of the transient receptor potential ankyrin 1 ion channel in the inflamed human and mouse colon and its protective roles. PLoS One 2014;9:e108164.

70 Bertin S, Aoki-Nonaka Y, de Jong PR, Nohara LL, Xu H, Stanwood SR, Srikanth S, Lee J, To K, Abramson L, Yu T, Han T, Touma R, Li X, Gonzalez-Navajas JM, Herdman S, Corr M, Fu G, Dong H, Gwack Y, Franco A, Jefferies WA, Raz E: The ion channel TRPV1 regulates the activation and proinflammatory properties of CD4(+) T cells. Nat Immunol 2014;15: 1055-1063. 
71 Matsumoto K, Hosoya T, Tashima K, Namiki T, Murayama T, Horie S: Distribution of transient receptor potential vanilloid 1 channelexpressing nerve fibers in mouse rectal and colonic enteric nervous system: relationship to peptidergic and nitrergic neurons. Neuroscience 2011;172:518-534.

-72 Sipe WE, Brierley SM, Martin CM, Phillis BD, Cruz FB, Grady EF, Liedtke W, Cohen DM, Vanner S, Blackshaw LA, Bunnett NW: Transient receptor potential vanilloid 4 mediates protease activated receptor 2 -induced sensitization of colonic afferent nerves and visceral hyperalgesia. Am J Physiol Gastrointest Liver Physiol 2008;294:G1288-G1298.

-73 Cenac N, Altier C, Chapman K, Liedtke W, Zamponi G, Vergnolle N: Transient receptor potential vanilloid-4 has a major role in visceral hypersensitivity symptoms. Gastroenterology 2008;135:937-946, 946 e931-932.

-74 Fichna J, Mokrowiecka A, Cygankiewicz AI, Zakrzewski PK, Malecka-Panas E, Janecka A, Krajewska WM, Storr MA: Transient receptor potential vanilloid 4 blockade protects against experimental colitis in mice: a new strategy for inflammatory bowel diseases treatment? Neurogastroenterol Motil 2012; 24:e557-e560.

75 D’Aldebert E, Cenac N, Rousset P, Martin L, Rolland C, Chapman K, Selves J, Alric L, Vinel JP, Vergnolle N: Transient receptor potential vanilloid 4 activated inflammatory signals by intestinal epithelial cells and colitis in mice. Gastroenterology 2011;140:275-285.

-76 Yu S, Ouyang A: TRPA1 in bradykinin-induced mechanical hypersensitivity of vagal C fibers in guinea pig esophagus. Am J Physiol Gastrointest Liver Physiol 2009;296:G255G265.

-77 Holzer P, Maggi CA: Dissociation of dorsal root ganglion neurons into afferent and efferent-like neurons. Neuroscience 1998;86:389398.

-78 Bartho L, Benko R, Patacchini R, Petho G, Holzer-Petsche U, Holzer P, Lazar Z, Undi S, Illenyi L, Antal A, Horvath OP: Effects of capsaicin on visceral smooth muscle: a valuable tool for sensory neurotransmitter identification. Eur J Pharmacol 2004;500:143-157.

79 Bartho L, Benko R, Holzer-Petsche U, Holzer $\mathrm{P}$, Undi S, Wolf M: Role of extrinsic afferent neurons in gastrointestinal motility. Eur Rev Med Pharmacol Sci 2008;12(suppl 1):21-31.

\$0 Mozsik G, Szolcsanyi J, Domotor A: Capsaicin research as a new tool to approach of the human gastrointestinal physiology, pathology and pharmacology. Inflammopharmacology 2007;15:232-245.

81 Diogenes A, Ferraz CC, Akopian AN, Henry MA, Hargreaves KM: LPS sensitizes TRPV1 via activation of TLR4 in trigeminal sensory neurons. J Dent Res 2011;90:759-764.

-82 Ferraz CC, Henry MA, Hargreaves KM, Diogenes A: Lipopolysaccharide from Porphyromonas gingivalis sensitizes capsaicin-sensitive nociceptors. J Endod 2011;37:45-48.
83 Clark N, Keeble J, Fernandes ES, Starr A, Liang L, Sugden D, de Winter P, Brain SD: The transient receptor potential vanilloid 1 (TRPV1) receptor protects against the onset of sepsis after endotoxin. FASEB J 2007;21: 3747-3755.

84 Meng J, Ovsepian SV, Wang J, Pickering M, Sasse A, Aoki KR, Lawrence GW, Dolly JO: Activation of TRPV1 mediates calcitonin generelated peptide release, which excites trigeminal sensory neurons and is attenuated by a retargeted botulinum toxin with anti-nociceptive potential. J Neurosci 2009;29:4981-4992.

85 Feng Y, Tang Y, Guo J, Wang X: Inhibition of LPS-induced TNF-alpha production by calcitonin gene-related peptide (CGRP) in cultured mouse peritoneal macrophages. Life Sci 1997;61:PL 281-287.

86 Altmayr F, Jusek G, Holzmann B: The neuropeptide calcitonin gene-related peptide causes repression of tumor necrosis factoralpha transcription and suppression of ATF-2 promoter recruitment in Toll-like receptorstimulated dendritic cells. J Biol Chem 2010; 285:3525-3531.

87 Meseguer V, Alpizar YA, Luis E, Tajada S, Denlinger B, Fajardo O, Manenschijn JA, Fernandez-Pena C, Talavera A, Kichko T, Navia B, Sanchez A, Senaris R, Reeh P, Perez-Garcia MT, Lopez-Lopez JR, Voets T, Belmonte C, Talavera K, Viana F: TRPA1 channels mediate acute neurogenic inflammation and pain produced by bacterial endotoxins. Nat Commun 2014;5:3125.

-88 Andrade YN, Fernandes J, Lorenzo IM, Arniges M, Valverde MA: The TRPV4 channel in ciliated epithelia; in Liedtke WB, Heller S (eds): TRP Ion Channel Function in Sensory Transduction and Cellular Signaling Cascades, chapt 30. Boca Raton, CRC Press, 2007.

89 Fernandes ES, Vong CT, Quek S, Cheong J, Awal S, Gentry C, Aubdool AA, Liang L, Bodkin JV, Bevan S, Heads R, Brain SD: Superoxide generation and leukocyte accumulation: key elements in the mediation of leukotriene $\mathrm{B}(4)$-induced itch by transient receptor potential ankyrin 1 and transient receptor potential vanilloid 1. FASEB J 2013;27:16641673.

90 Caterina MJ, Julius D: The vanilloid receptor: a molecular gateway to the pain pathway. Ann Rev Neurosci 2001;24:487-517.

91 Geppetti P, Trevisani M: Activation and sensitisation of the vanilloid receptor: role in gastrointestinal inflammation and function. $\mathrm{Br} \mathrm{J}$ Pharmacol 2004;141:1313-1320.

92 Holzer P: The pharmacological challenge to tame the transient receptor potential vanilloid-1 (TRPV1) nocisensor. Br J Pharmacol 2008;155:1145-1162.

93 Gonlachanvit S, Mahayosnond A, Kullavanijaya P: Effects of chili on postprandial gastrointestinal symptoms in diarrhoea predominant irritable bowel syndrome: evidence for capsaicin-sensitive visceral nociception hypersensitivity. Neurogastroenterol Motil 2009;21:23-32.
$\$ 94$ Szitter I, Pozsgai G, Sandor K, Elekes K, Kemeny A, Perkecz A, Szolcsanyi J, Helyes Z, Pinter E: The role of transient receptor potential vanilloid 1 (TRPV1) receptors in dextran sulfate-induced colitis in mice. J Mol Neurosci 2010;42:80-88.

\$5 Maggi CA: Tachykinins and calcitonin gene-related peptide (CGRP) as co-transmitters released from peripheral endings of sensory nerves. Prog Neurobiol 1995;45:198.

-96 Pinter E, Helyes Z, Szolcsanyi J: Inhibitory effect of somatostatin on inflammation and nociception. Pharmacol Ther 2006;112: 440-456.

\$9 McVey DC, Vigna SR: The capsaicin VR1 receptor mediates substance $\mathrm{P}$ release in toxin A-induced enteritis in rats. Peptides 2001;22:1439-1446.

$\$ 98$ Cenac N, Altier C, Motta JP, d'Aldebert E, Galeano S, Zamponi GW, Vergnolle N: Potentiation of TRPV4 signalling by histamine and serotonin: an important mechanism for visceral hypersensitivity. Gut 2010;59:481488.

$\$ 99$ De Petrocellis L, Orlando P, Moriello AS, Aviello G, Stott C, Izzo AA, Di Marzo V: Cannabinoid actions at TRPV channels: effects on TRPV 3 and TRPV4 and their potential relevance to gastrointestinal inflammation. Acta Physiol (Oxf) 2012;204:255266.

100 Ueda T, Shikano M, Kamiya T, Joh T, Ugawa S: The TRPV4 channel is a novel regulator of intracellular $\mathrm{Ca} 2+$ in human esophageal epithelial cells. Am J Physiol Gastrointest Liver Physiol 2011;301:G138-G147.

101 Pozsgai G, Bodkin JV, Graepel R, Bevan S, Andersson DA, Brain SD: Evidence for the pathophysiological relevance of TRPA1 receptors in the cardiovascular system in vivo. Cardiovasc Res 2010;87:760-768.

102 Kimball ES, Prouty SP, Pavlick KP, Wallace NH, Schneider CR, Hornby PJ: Stimulation of neuronal receptors, neuropeptides and cytokines during experimental oil of mustard colitis. Neurogastroenterol Motil 2007; 19:390-400.

103 Ceppa E, Cattaruzza F, Lyo V, Amadesi S, Pelayo JC, Poole DP, Vaksman N, Liedtke W, Cohen DM, Grady EF, Bunnett NW, Kirkwood KS: Transient receptor potential ion channels V4 and A1 contribute to pancreatitis pain in mice. Am J Physiol Gastrointest Liver Physiol 2010;299:G556-G571.

104 Trevisani M, Siemens J, Materazzi S, Bautista DM, Nassini R, Campi B, Imamachi N, Andre E, Patacchini R, Cottrell GS, Gatti R, Basbaum AI, Bunnett NW, Julius D, Geppetti P: 4-hydroxynonenal, an endogenous aldehyde, causes pain and neurogenic inflammation through activation of the irritant receptor TRPA1. Proc Natl Acad Sci USA 2007;104:13519-13524.
TRP Channels and CS in Intestinal Inflammation
Pathobiology 2017;84:1-15 DOI: $10.1159 / 000446568$ 
105 Engel MA, Becker C, Reeh PW, Neurath MF: Role of sensory neurons in colitis: increasing evidence for a neuroimmune link in the gut. Inflamm Bowel Dis 2011;17: 1030-1033.

106 Matsuda H, Ochi M, Nagatomo A, Yoshikawa M: Effects of allyl isothiocyanate from horseradish on several experimental gastric lesions in rats. Eur J Pharmacol 2007;561: 172-181.

107 Malsch P, Andratsch M, Vogl C, Link AS, Alzheimer C, Brierley SM, Hughes PA, Kress M: Deletion of interleukin-6 signal transducer GP130 in small sensory neurons attenuates mechanonociception and downregulates TRPA1 expression. J Neurosci 2014;34:9845-9856.

108 Schoeber JP, Hoenderop JG, Bindels RJ: Concerted action of associated proteins in the regulation of TRPV5 and TRPV6. Biochem Soc Trans 2007;35:115-119.

109 Fukushima A, Aizaki Y, Sakuma K: Shortchain fatty acids induce intestinal transient receptor potential vanilloid type 6 expression in rats and Caco-2 cells. J Nutr 2009; 139:20-25.

110 Bartik L, Whitfield GK, Kaczmarska M, Lowmiller CL, Moffet EW, Furmick JK, Hernandez Z, Haussler CA, Haussler MR, Jurutka PW: Curcumin: a novel nutritionally derived ligand of the vitamin $\mathrm{D}$ receptor with implications for colon cancer chemoprevention. J Nutr Biochem 2010;21:11531161.

-111 Clapham DE, Garbers DL: International Union of Pharmacology. L. Nomenclature and structure-function relationships of CatSper and two-pore channels. Pharmacol Rev 2005;57:451-454.

112 Nijenhuis T, Vallon V, van der Kemp AW, Loffing J, Hoenderop JG, Bindels RJ: Enhanced passive $\mathrm{Ca} 2+$ reabsorption and reduced Mg2+ channel abundance explains thiazide-induced hypocalciuria and hypomagnesemia. J Clin Invest 2005;115:16511658.

113 Benn BS, Ajibade D, Porta A, Dhawan P, Hediger M, Peng JB, Jiang Y, Oh GT, Jeung EB, Lieben L, Bouillon R, Carmeliet G, Christakos S: Active intestinal calcium transport in the absence of transient receptor potential vanilloid type 6 and calbindinD9k. Endocrinology 2008;149:3196-3205.

-114 Suzuki Y, Landowski CP, Hediger MA: Mechanisms and regulation of epithelial $\mathrm{Ca} 2+$ absorption in health and disease. Annu Rev Physiol 2008;70:257-271.

115 Huybers S, Apostolaki M, van der Eerden BC, Kollias G, Naber TH, Bindels RJ, Hoenderop JG: Murine TNF(deltaARE) Crohn's disease model displays diminished expression of intestinal $\mathrm{Ca} 2+$ transporters. Inflamm Bowel Dis 2008;14:803-811.

116 Stichting tegen Kanker: Rookgedrag in België, 2013.
117 Lim SS, Vos T, Flaxman AD, Danaei G, et al: A comparative risk assessment of burden of disease and injury attributable to 67 risk factors and risk factor clusters in 21 regions, 1990-2010: a systematic analysis for the Global Burden of Disease Study 2010. Lancet 2012;380:2224-2260.

118 Oberg M, Jaakkola MS, Woodward A, Peruga A, Pruss-Ustun A: Worldwide burden of disease from exposure to second-hand smoke: a retrospective analysis of data from 192 countries. Lancet 2011;377:139-146.

119 Bracke KR, D’Hulst A I, Maes T, Moerloose KB, Demedts IK, Lebecque S, Joos GF, Brusselle GG: Cigarette smoke-induced pulmonary inflammation and emphysema are attenuated in CCR6-deficient mice. J Immunol 2006; 177:4350-4359.

120 Smit LA, Kogevinas M, Anto JM, Bouzigon E, Gonzalez JR, Le Moual N, Kromhout H, Carsin AE, Pin I, Jarvis D, Vermeulen R, Janson C, Heinrich J, Gut I, Lathrop M, Valverde MA, Demenais F, Kauffmann F: Transient receptor potential genes, smoking, occupational exposures and cough in adults. Respir Res 2012;13:26.

121 Caceres AI, Brackmann M, Elia MD, Bessac BF, del Camino D, D'Amours M, Witek JS, Fanger CM, Chong JA, Hayward NJ, Homer RJ, Cohn L, Huang XZ, Moran MM, Jordt SE: A sensory neuronal ion channel essential for airway inflammation and hyperreactivity in asthma. Proc Natl Acad Sci USA 2009;106:9099-9104.

122 Andrè E, Campi B, Materazzi S, Trevisani M, Amadesi S, Massi D, Creminon C, Vaksman N, Nassini R, Civelli M, Baraldi PG, Poole DP, Bunnett NW, Geppetti P, Patacchini R: Cigarette smoke-induced neurogenic inflammation is mediated by alpha,beta-unsaturated aldehydes and the TRPA1 receptor in rodents. J Clin Invest 2008;118:2574-2582.

123 Talavera K, Gees M, Karashima Y, Meseguer VM, Vanoirbeek JAJ, Damann N, Everaerts W, Benoit M, Janssens A, Vennekens R, Viana F, Nemery B, Nilius B, Voets T: Nicotine activates the chemosensory cation channel TRPA1. Nat Neurosci 2009;12: 1293-1299.

124 Nassini R, Pedretti P, Moretto N, Fusi C, Carnini C, Facchinetti F, Viscomi AR, Pisano AR, Stokesberry S, Brunmark C, Svitacheva N, McGarvey L, Patacchini R, Damholt AB, Geppetti P, Materazzi S: Transient receptor potential ankyrin 1 channel localized to non-neuronal airway cells promotes non-neurogenic inflammation. PLoS One 2012; 7:e42454.

125 Baxter M, Eltom S, Dekkak B, Yew-Booth L, Dubuis ED, Maher SA, Belvisi MG, Birrell MA: Role of transient receptor potential and pannexin channels in cigarette smoke-triggered ATP release in the lung. Thorax 2014; 69:1080-1089.
26 Lunney PC, Kariyawasam VC, Wang RR, Middleton KL, Huang T, Selinger CP, Andrews JM, Katelaris PH, Leong RW: Smoking prevalence and its influence on disease course and surgery in Crohn's disease and ulcerative colitis. Aliment Pharmacol Ther 2015;42:61-70.

127 Higuchi LM, Khalili H, Chan AT, Richter JM, Bousvaros A, Fuchs CS: A prospective study of cigarette smoking and the risk of inflammatory bowel disease in women. Am J Gastroenterol 2012;107:1399-1406.

128 Calkins BM: A meta-analysis of the role of smoking in inflammatory bowel disease. Digest Dis Sci 1989;34:1841-1854.

129 Mahid SS, Minor KS, Soto RE, Hornung CA, Galandiuk S: Smoking and inflammatory bowel disease: a meta-analysis. Mayo Clin Proc 2006;81:1462-1471.

130 Boyko EJ, Koepsell TD, Perera DR, Inui TS: Risk of ulcerative colitis among former and current cigarette smokers. N Engl J Med 1987;316:707-710.

131 Lindberg E, Tysk C, Andersson K, Jarnerot G: Smoking and inflammatory bowel disease. A case control study. Gut 1988;29:352357.

132 Franceschi S, Panza E, La Vecchia C, Parazzini F, Decarli A, Bianchi Porro G: Nonspecific inflammatory bowel disease and smoking. Am J Epidemiol 1987;125:445-452.

133 Corrao G, Tragnone A, Caprilli R, Trallori G, Papi C, Andreoli A, Di Paolo M, Riegler G, Rigo GP, Ferrau O, Mansi C, Ingrosso M, Valpiani D: Risk of inflammatory bowel disease attributable to smoking, oral contraception and breastfeeding in Italy: a nationwide case-control study. Cooperative investigators of the Italian group for the study of the colon and the rectum (GISC). Int J Epidemiol 1998;27:397-404.

134 Tobin MV, Logan RF, Langman MJ, McConnell RB, Gilmore IT: Cigarette smoking and inflammatory bowel disease. Gastroenterology 1987;93:316-321.

135 Garcia Rodriguez LA, Gonzalez-Perez A, Johansson S, Wallander MA: Risk factors for inflammatory bowel disease in the general population. Aliment Pharmacol Ther 2005;22:309-315

136 Hugot JP, Chamaillard M, Zouali H, Lesage S, Cezard JP, Belaiche J, Almer S, Tysk C, O'Morain CA, Gassull M, Binder V, Finkel Y, Cortot A, Modigliani R, Laurent-Puig P, Gower-Rousseau C, Macry J, Colombel JF, Sahbatou M, Thomas G: Association of NOD2 leucine-rich repeat variants with susceptibility to Crohn's disease. Nature 2001;411:599-603.

137 Matsunaga K, Klein TW, Friedman H, Yamamoto Y: Involvement of nicotinic acetylcholine receptors in suppression of antimicrobial activity and cytokine responses of alveolar macrophages to legionella pneumophila infection by nicotine. J Immunol 2001;167:6518-6524. 
138 Allais L, Kerckhof FM, Verschuere S, Bracke KR, De Smet R, Laukens D, Van den Abbeele P, De Vos M, Boon N, Brusselle GG, Cuvelier CA, Van de Wiele T: Chronic cigarette smoke exposure induces microbial and inflammatory shifts and mucin changes in the murine gut. Environ Microbiol 2016;18: 1352-1363.

139 Ueno A, Jijon H, Traves S, Chan R, Ford K, Beck PL, Iacucci M, Fort Gasia M, Barkema HW, Panaccione R, Kaplan GG, Proud D, Ghosh S: Opposing effects of smoking in ulcerative colitis and Crohn's disease may be explained by differential effects on dendritic cells. Inflamm Bowel Dis 2014;20:800-810.

140 Zuo L, Li Y, Wang H, Wu R, Zhu W, Zhang W, Cao L, Gu L, Gong J, Li N, Li J: Cigarette smoking is associated with intestinal barrier dysfunction in the small intestine but not in the large intestine of mice. J Crohns Colitis 2014;8:1710-1722.

141 Sher ME, Bank S, Greenberg R, Sardinha TC, Weissman S, Bailey B, Gilliland R, Wexner SD: The influence of cigarette smoking on cytokine levels in patients with inflammatory bowel disease. Inflamm Bowel Dis 1999;5:73-78.

142 Verschuere S, Bracke KR, Demoor T, Plantinga $M$, Verbrugghe $P$, Ferdinande L, Lambrecht BN, Brusselle GG, Cuvelier CA: Cigarette smoking alters epithelial apoptosis and immune composition in murine GALT. Lab Invest 2011;91:1056-1067.
143 Pauwels NS, Bracke KR, Maes T, Pilette C, Joos GF, Brusselle GG: The role of interleukin-6 in pulmonary and systemic manifestations in a murine model of chronic obstructive pulmonary disease. Exp Lung Res 2010;36:469-483.

144 Matsumoto K, Kurosawa E, Terui H, Hosoya T, Tashima K, Murayama T, Priestley JV, Horie S: Localization of TRPV1 and contractile effect of capsaicin in mouse large intestine: high abundance and sensitivity in rectum and distal colon. Am J Physiol Gastrointest Liver Physiol 2009;297:G348G360.

145 Biedermann L, Zeitz J, Mwinyi J, SutterMinder E, Rehman A, Ott SJ, Steurer-Stey C, Frei A, Frei P, Scharl M, Loessner MJ, Vavricka SR, Fried M, Schreiber S, Schuppler M, Rogler G: Smoking cessation induces profound changes in the composition of the intestinal microbiota in humans. PLoS One 2013;8:e59260.

146 Verschuere S, Allais L, Bracke KR, Lippens $\mathrm{S}$, De Smet R, Vandenabeele P, Brusselle GG, Cuvelier CA: Cigarette smoke and the terminal ileum: increased autophagy in murine follicle-associated epithelium and Peyer's patches. Histochem Cell Biol 2012;137: 293-301.

147 Ryter SW, Choi AMK: Autophagy in lung disease pathogenesis and therapeutics. Redox Biol 2015;4:215-225.

148 Wu LJ, Sweet TB, Clapham DE: International Union of Basic and Clinical Pharmacology. LXXVI. Current progress in the mammalian TRP ion channel family. Pharmacol Rev 2010;62:381-404.
49 Jostins L, Ripke S, Weersma RK, et al: Hostmicrobe interactions have shaped the genetic architecture of inflammatory bowel disease. Nature 2012;491:119-124.

150 Ao R, Wang Y, Zhnag DR, Du YQ: Role of TLR4 rs4986790a $>g$ and rs4986791c $>t$ polymorphisms in the risk of inflammatory bowel disease. Gastroenterol Res Pract 2015;2015:141070.

151 Zhu G, Investigators I, Gulsvik A, Bakke P, Ghatta S, Anderson W, Lomas DA, Silverman EK, Pillai SG: Association of TRPV4 gene polymorphisms with chronic obstructive pulmonary disease. Hum Mol Genet 2009;18:2053-2062.

152 Cantero-Recasens G, Gonzalez JR, Fandos C, Duran-Tauleria E, Smit LA, Kauffmann F, Anto JM, Valverde MA: Loss of function of transient receptor potential vanilloid 1 (TRPV1) genetic variant is associated with lower risk of active childhood asthma. J Biol Chem 2010;285:27532-27535.

153 Lowin T, Apitz M, Anders S, Straub RH: Anti-inflammatory effects of $\mathrm{N}$-acylethanolamines in rheumatoid arthritis synovial cells are mediated by TRPV 1 and TRPA1 in a COX-2 dependent manner. Arthritis Res Ther 2015;17:321.

154 Kishimoto E, Naito Y, Handa O, Okada H, Mizushima K, Hirai Y, Nakabe N, Uchiyama K, Ishikawa T, Takagi T, Yagi N, Kokura S, Yoshida N, Yoshikawa T: Oxidative stress-induced posttranslational modification of TRPV1 expressed in esophageal epithelial cells. Am J Physiol Gastrointest Liver Physiol 2011;301:G230-G238. 